\title{
THE PROPERTIES OF ALOE VERA POWDER USING CASSAVA MALTODEXTRIN AS CARRIER AGENTS
}

\author{
Karakteristik Bubuk Aloe vera yang Diproduksi Menggunakan \\ Maltodekstrin Ubi Kayu sebagai Bahan Pembawa
}

\author{
Maherawati and Lucky Hartanti \\ Department of Food Science and Technology, Faculty of Agriculture, \\ Universitas Tanjungpura, Pontianak, West Kalimantan, Indonesia 78124 \\ e-mail: maherawati@faperta.untan.ac.id
}

\begin{abstract}
Abstrak: Tujuan penelitian ini adalah untuk menentukan karakteristik bubuk Aloe vera yang diproduksi dengan bahan pembawa berupa maltodekstrin ubi kayu dalam jumlah yang berbeda. Total padatan terlarut campuran Aloe vera dan maltodekstrin sebelum proses spray drying diatur sebesar $20 \%$, 25\%, dan 30\%. Hasil penelitian menunjukkan bahwa semua bubuk Aloe vera yang dihasilkan mempunyai aktivitas air dalam kisaran yang aman sebagai bahan kering (0,32-0,38). Penambahan maltodekstrin terbanyak menyebabkan kadar air terendah (4,49\%). Penambahan maltodekstrin ubi kayu meningkatkan kecerahan, kemudahan mengalir bubuk, mengurangi kadar air, dan menurunkan kohesivitas antar partikel. Semakin banyak maltodekstrin yang ditambahkan menyebabkan penurunan kelarutan dan pembasahan bubuk Aloe vera. Bubuk Aloe vera mempunyai bentuk bundar dengan ukuran tidak seragam. Semakin banyak maltodekstrin yang ditambahkan menghasilkan partikel bubuk yang semakin besar.
\end{abstract}

Kata kunci: aloe vera, ubi kayu, maltodekstrin, karakteristik bubuk

\begin{abstract}
This research aims to determine the powder properties of Aloe vera powder in a different amount of cassava maltodextrin addition. The total soluble solid in Aloe vera extract before spray drying was adjusted to the total soluble solid as $20 \%, 25 \%$, and $30 \%(\mathrm{w} / \mathrm{v})$ by adding the appropriate amount of cassava maltodextrin as carrier agents. The results showed that all Aloe vera powder has the water activity in the range of safe water activity for dried food $(0.32-0.38)$. The highest cassava maltodextrin added produce Aloe vera powder with the lowest water content $(4.49 \%)$. The addition of cassava maltodextrin increased brightness and flowability of the Aloe vera powder, reduced water content, decreased the cohesiveness between powder particles. More of cassava maltodextrin addition caused a decrease in solubility and wettability time on Aloe vera powder. The Aloe vera powder particle had a round shape and uniform size. The higher cassava maltodextrin addition made a larger size of Aloe vera powder particle.
\end{abstract}

Keywords: aloe vera, cassava, maltodextrin, powder characteristic

\section{INTRODUCTION}

Aloe vera is included in the Aloeaceae family. The genus Aloe contains over 400 different species with Aloe barbadensis Miller, Aloe aborescens, and Aloe chinensis being the most popular (Yagi et al., 1998). Main products from Aloe vera, i.e., aloe latex and aloe gel. Aloe latex is an exudate from the tubules in the outer skin of the leaves, while aloe gel is the colorless gel found in the inner part of the fresh leaves (Reynolds and Dweck, 1999). The gel consists mainly of water $(>98 \%)$ and polysaccharides (pectins, cellulose, hemicelluloses, glucomannan, acemannan, and mannose derivatives) (Lee et al., 2001). It is traditionally used both topically and internally to treat various minor health problems such as treatment of wounds, minor burn, skin irritation, constipation, cough, ulcer, diabetes, headache, arthritis, and immune-system deficiencies (Vogler and Ernest, 1999; Eshun and $\mathrm{He}, 2004$ ).

Aloe vera high moisture content make it perishable and difficult to handle. One of the most suitable solutions for those problems is produce Aloe vera extracts and dried to a powder (Ozdikicierler et al., 2014). The powder form has some advantages such as long shelf-life, low transportation cost, and storage capacity, and it can be used easily 
in various needs. In addition, material weight and bulk reduction provides greater variety and convenience for consumer.

Drying method that suitable to produce Aloe vera powder is spray drying because of short contact time with medium and the high rate of evaporation that gives high-quality product compared to conventional drying methods (Gong et al., 2008). This method needs an ingredient as carrier agents to encapsulate the plant extracts and convert it into powdered form. Carrier agent is selected based on requisite of powder property such as stability, yield, solubility, and absorbency. Some of the material that usually used as carrier agents in spray drying is maltodextrin, cyclodextrin, lactose, starch, and modified starch (Matsuura et al., 2015).

Maltodextrin is non-sweet polysaccharide polymers that consist of D-glucose units linked primarily by $\alpha(1,4)$-glycosidic bond and that have a dextrose equivalent (DE) of less than 20. It is widely used as a carrier agent because of its non-toxicity, cheap, strongly hydrophilic, and not surfaceactive in emulsions (Udomrati and Gohtani, 2015). The differences in maltodextrin from different sources used in spray drying caused differences in powder physicochemical properties. Cassava is a primary carbohydrate source in Indonesia that potentially utilized as a raw material to produce maltodextrin powder. This study aims to determine the powder properties of Aloe vera powder along with the effects of cassava maltodextrin different amount addition.

\section{METHODS}

\section{Materials}

Fresh Aloe vera was obtained from a local farmer in Pontianak, Indonesia. Cassava to produce maltodextrin was obtained from a local farmer in Gunung Kidul, Yogyakarta, Indonesia. Liquozyme was purchased from Novozym (Sigma Aldrich, USA), chemicals material were purchased from Merck (Darmstadt, Germany).

\section{Cassava Maltodextrin Production}

Cassava roots were peeled, washed, cut in small size (approx. 1x1 $1 \times 7 \mathrm{~cm}^{3}$ ), dried at $70^{\circ} \mathrm{C}$ for 60 hours, then milled into cassava flour and dissolved in water to concentration of $20 \%(\mathrm{w} / \mathrm{v})$. The solution was adjusted at $\mathrm{pH}$ 5.5 , with the addition of $\mathrm{HCL} 1 \mathrm{M}$ and heated at $85^{\circ} \mathrm{C}$ for 10 minutes (Shanavas et al., 2011). Subsequently, $25 \mu \mathrm{L}$ Liquozyme was added (Johnson et al., 2011) and incubated at $85^{\circ} \mathrm{C}$ for 30 min with stirring. The incubation was stopped and solution was dried at $50-60^{\circ} \mathrm{C}$ for five days. Cassava maltodextrin was kept at $4^{\circ} \mathrm{C}$.

\section{Aloe vera Extract Preparation}

Aloe vera leaves were peeled, cut, grinded, and filtered. The filtrate was kept overnight in a cool room, then centrifuged at $3500 \mathrm{rpm}$ for 15 minutes. The supernatant was filtered using vacuum filter to obtain Aloe vera extract.

\section{Aloe vera Powder Drying}

In order to obtain extract with total soluble solid (TSS) of $20 \%, 25 \%$, and $30 \%$ $(\mathrm{w} / \mathrm{v}), 1 \mathrm{~mL}$ Aloe vera extract was mixed with $0.5-0.05 \mathrm{~g}$ of cassava maltodextrin then measured its total soluble solid. A regression curve made based on data so that it can be known the comparison of Aloe vera extract and maltodextrin to obtain total soluble solid, which is desired. The solution was dried in spray dryer with inlet temperature of $105^{\circ} \mathrm{C}$ and outlet temperature of $60^{\circ} \mathrm{C}$ based on Rahayuni (2002). Dried powder was collected from cyclone separator, packed in sealed plastics, and kept in cold storage.

\section{Physical Properties Analysis}

Aloe vera powder physical properties consists of moisture content (gravimetric methods), water activity (Aqualab Pawkit, portable water activity meter), and ash content (gravimetric method). Aloe vera powder colors $\left(L^{*}, a^{*}\right.$, and $b^{*}$ value) were measured with Chromameter CR-400 (Konica Minolta Optics, Inc., Japan). L* 
value measure its lightness, which ranges between 0 to 100 . The increases in $a^{*}$ value in positive and negative scales correspond to increases in red or green color, respectively. The $b^{*}$ value represents color ranging from yellow (+) to blue (-). The chroma and hue angle $\left({ }^{\circ}\right)$ were calculated by using Eqs. (1), and (2).

$$
\begin{aligned}
& \text { Chroma }=\left(a^{* 2}+b^{* 2}\right)^{1 / 2} \\
& \text { Hue angle }\left(^{\circ}\right)=\tan -1\left(\frac{b x}{a}\right)
\end{aligned}
$$

Browning index (BI) represents about brown color purity and is considered as important parameter associated with browning (Lopez-malo et al., 1998). The browning index was calculated by using Eqs. (3), and (4).

$$
\begin{gathered}
\text { Browning index }=\frac{[100(x-0.31)}{0.17} \ldots \ldots \ldots . . \\
x=\frac{\left(a *+1.75 L^{*}\right)}{\left(5.645 L^{*}+a^{*}-3.012 b *\right)} \ldots \ldots \ldots .
\end{gathered}
$$

\section{Powder Properties Analysis}

Aloe vera powder properties consist of bulk density, tapped density, wettability, and solubility, according to Caliskan and Dirim (2016). The bulk density was determined by putting $20 \mathrm{~g}$ of powder into $100 \mathrm{ml}$ graduated cylinder. The measured volume read directly from the cylinder was to calculate the bulk density $\left(\rho_{\text {bulk }}\right)$ according to mass ratio to volume. In order to determine tapped density $\left(\rho_{\text {tapped }}\right)$, the cylinder was tapped for 120 times, and sample volume was read. Powder flowability and cohesiveness value was evaluated in terms of Carr Index $(\mathrm{Cl})$ and Hausner Ratio (HR), respectively. Both $\mathrm{Cl}$ and $\mathrm{HR}$ were calculated from powder bulk $\left(\rho_{\text {bulk }}\right)$ and tapped $\left(\rho_{\text {tapped }}\right)$ densities using Eqs. (5), and (6) as shown below.

$$
\begin{array}{r}
\text { HR }=\frac{\text { ptappec }}{\rho \text { phulk }} \\
\text { CI }=\frac{\text { (ptapped }- \text { pbulk })}{\text { ptapped }} \times 10 C \ldots . . .
\end{array}
$$

Aloe vera powder average wettability time (s) was determined by measuring the time for thoroughly wetting $10 \mathrm{~g}$ of sample placed around a $250 \mathrm{ml}$ beaker containing $100 \mathrm{ml}$ of distilled water (at $25^{\circ} \mathrm{C}$ ). Aloe vera powder solubility was expressed as the average solubility time (s) of powder products and determined by dissolving $2 \mathrm{~g}$ of sample in $50 \mathrm{ml}$ of deionized water at $30^{\circ} \mathrm{C}$ under continuous stirring using magnetic stirrer. Required time to dissolve the powder completely was expressed as sample average solubility time.

\section{Aloe vera Powder Morphology}

Aloe vera powder particle morphology was evaluated using scanning electron microscope (FEI Inspect S50). The powder attached to double-sided adhesive was mounted on SEM stubs of $9.9 \mathrm{~mm}$ diameter. SEM was operated at $10 \mathrm{kV}$ using enlarged 3000x ETD detector with a tilt of $0^{\circ}$.

All data in this study were analyzed using statistical analysis software (SAS Institute, USA). This data was also subjected to analysis of variance (ANOVA), and Duncan's multiple range test $(\alpha=0.05)$ was used to determine the difference between means. Drying experiments were replicated twice and all the analyses were triplicated.

\section{RESULT AND DISCUSSION}

\section{Aloe vera Powder Physical Properties}

Water content and water activity are essential parameters in powder materials as they are related to product dissolubility and shelf life. In this study, Aloe vera powder with the highest amount of maltodextrin addition (TSS 30\% w/v) has the lowest water content (Table 1). Increasing concentration of maltodextrin addition should increase the total soluble solids, which resulted in a decrease in water content. Aloe vera powder moisture was significantly affected by maltodextrin concentration $(p<0.05)$. 
Table 1. Aloe vera Powder Physical Properties

\begin{tabular}{|c|c|c|c|}
\hline \multirow[t]{2}{*}{ Physical properties } & \multicolumn{3}{|c|}{ Total soluble solids (w/v) of cassava maltodextrin addition } \\
\hline & $20 \%$ & $25 \%$ & $30 \%$ \\
\hline Moisture content (\%) & $5.01 \pm 0.09^{c}$ & $4.78 \pm 0.15^{\mathrm{b}}$ & $4.49 \pm 0.05^{\mathrm{a}}$ \\
\hline Water activity & $0.38 \pm 0.02^{\mathrm{a}}$ & $0.35 \pm 0.05^{a}$ & $0.32 \pm 0.02^{\mathrm{a}}$ \\
\hline Ash content (\%) & $2.51 \pm 0.01^{\mathrm{b}}$ & $2.42 \pm 0.09^{\mathrm{ab}}$ & $2.35 \pm 0.02^{\mathrm{a}}$ \\
\hline$L^{*}$ & $82.71 \pm 0.78^{\mathrm{a}}$ & $88.21 \pm 0.28^{c}$ & $87.07 \pm 0.28^{b}$ \\
\hline$a^{*}$ & $3.94 \pm 0.12^{b}$ & $3.61 \pm 0.08^{a}$ & $3.47 \pm 0.06^{\mathrm{a}}$ \\
\hline$b^{*}$ & $11.62 \pm 0.62^{c}$ & $9.14 \pm 0.23^{\mathrm{a}}$ & $9.98 \pm 0.2^{\mathrm{b}}$ \\
\hline Chroma & $12.27 \pm 0.63^{b}$ & $9.83 \pm 0.24^{a}$ & $10.57 \pm 0.21^{a}$ \\
\hline Hue angle $\left({ }^{\circ}\right)$ & $0.69 \pm 0.045^{b}$ & $0.19 \pm 0.073^{a}$ & $0.27 \pm 0.01^{\mathrm{a}}$ \\
\hline Browning index & $18.31 \pm 0.78^{c}$ & $11.43 \pm 0.31^{\mathrm{a}}$ & $14.83 \pm 0.26^{b}$ \\
\hline
\end{tabular}

Different letters in the same row indicate a significant difference between treatment at $p<0.05$.

Water activity $\left(a_{w}\right)$ is an essential index for spray-dried powder because it can significantly affect powder shelf life. High water activity indicates more free water available for biochemical reactions and hence, shorter shelf life (Quek et al., 2007). Aloe vera powder water activity was still in safe water activity range for powder products, i.e., 0.32-0.38. Dried foods with low water activity value $(0.20-0.40)$ were considered as stable for browning, lipid oxidation, microbial growth, hydrolytic, and enzymatic reactions (Quek et al., 2007). It means spray-dried Aloe vera powder was relatively stable microbiologically.

Color measurement is an important quality indicator as it reflects sensory attractiveness and powder quality in spray drying process (Quek et al., 2007). Maltodextrin addition caused an increase in $L^{*}$ and decrease in $a^{*}$ and $b^{*}$ value. $L^{*}$ value is sample lightness, and $a^{*}$ value is red color while $b^{*}$ measures yellow color. It also caused brighter color in Aloe vera powder $(p<0.05)$. It was found that it decreased Hue angle and Chroma, and increased powder overall lightness. It significantly reduced the browning index value of Aloe vera powder $(p<0.05)$. Wang et al. (2006) reported that the coating material acts as a physical barrier to oxygen and light to ensure the protection from chemical and enzymatic destruction.

\section{Aloe vera Powder Properties}

Aloe vera powder bulk density increases with the increase in maltodextrin addition, in contrast to tapped density. The powder density indicates carrier agents effectiveness during drying process to powder form. Maltodextrin particles are more significant than the particles constituting the natural soluble solid content of Aloe vera extract. The higher maltodextrin addition should decrease water content so that it increases Aloe vera powder bulk density. The increasing amount of maltodextrin addition caused a linear decrease in moisture content that affected the increase in bulk density. A similar result was obtained by Marques et al. (2014) that reported the apparent densities of fruit pulps decreased linearly with moisture content during freeze-drying.

Tapped density is a significant characteristic of powder products in terms of storage and transportation. The density will affect powder flowability and cohesiveness. Carr index indicates the relationship between density and flowability, whereas Hausner Ratio shows the relationship between density and powder cohesivity. Aloe vera powder with maltodextrin addition in TSS $20 \%, 25 \%$, and $30 \%(\mathrm{w} / \mathrm{v})$ have resulted bulk density of $0.429-0.463 \mathrm{~kg} / \mathrm{m}^{3}$ and tapped density 
of $0.654-0.703 \mathrm{~kg} / \mathrm{m}^{3}$ (Table 2). Based on ANOVA $(\alpha=0.05)$, there was no significant difference in bulk density and tapped density in all concentrations of maltodextrin addition.

Table 2. Aloe vera Powder Powder Properties

\begin{tabular}{llll}
\hline Physical properties & \multicolumn{3}{c}{ Total soluble solids (w/v) } \\
\cline { 2 - 4 } & $\mathbf{2 0 \%}$ & \multicolumn{1}{c}{$\mathbf{2 5 \%}$} & \multicolumn{1}{c}{$\mathbf{3 0 \%}$} \\
\hline Bulk density $\left(\mathrm{kg} / \mathrm{m}^{3}\right)$ & $0.429 \pm 0.03$ & $0.436 \pm 0.011$ & $0.463 \pm 0.023$ \\
Tapped density $\left(\mathrm{kg} / \mathrm{m}^{3}\right)$ & $0.703 \pm 0.12$ & $0.673 \pm 0.048$ & $0.654 \pm 0.023$ \\
Carr Index & $38.98 \pm 6.37$ & $31.62 \pm 4.66$ & $29.17 \pm 1.08$ \\
Hausner Ratio & $1.64 \pm 0.18$ & $1.46 \pm 0.096$ & $1.41 \pm 0.022$ \\
\hline
\end{tabular}

Carr Index and Hausner Ratio can be calculated from bulk and tapped density. Powder flowability is important for manufacturer and end-user for packing, handling, measuring, transporting, bag filling and emptying, storage, dosing purpose, and selecting parameters for mixing and conditioning (Caliskan and Dirim, 2016). Its classification based on Carr Index $(\mathrm{Cl})$ is very good $(<15)$, good (15-20), fair (20-35), bad (35-45), and very bad (<45). The powder cohesiveness based on Hausner Ratio (HR) is classified as low $(<1.2)$, intermediate (1.21.4), and high (>1.4) (Jinapong et al., 2008).

This study showed that Aloe vera powder Carr Index is between $29.17 \pm 1.08$ to $38.98 \pm 6.37$, which fell between fair to bad groups. While Hausner Ratio is $1.41 \pm 0.022$ to $1.64 \pm 0.18$, which is included in intermediate to high group, more maltodextrin addition should decrease powder particles cohesiveness, so that decreased the flowability (Caliskan and Dirim, 2016).

\section{Aloe vera powder solubility and wettability}

Solubility is adequate criterion for evaluating powder behavior in aqueous solution and important property of reconstitution. It becomes significant characteristic for any dried powder that is reconstituted to desirable soluble solid content for industrial use (Ozdikicierler et al., 2014; Marques et al., 2014). of the Powder wettability can be characterized by the susceptibility of the particles to be penetrated by water (Marques et al., 2014). Aloe vera powder solubility and wettability time is given in Figure 1.

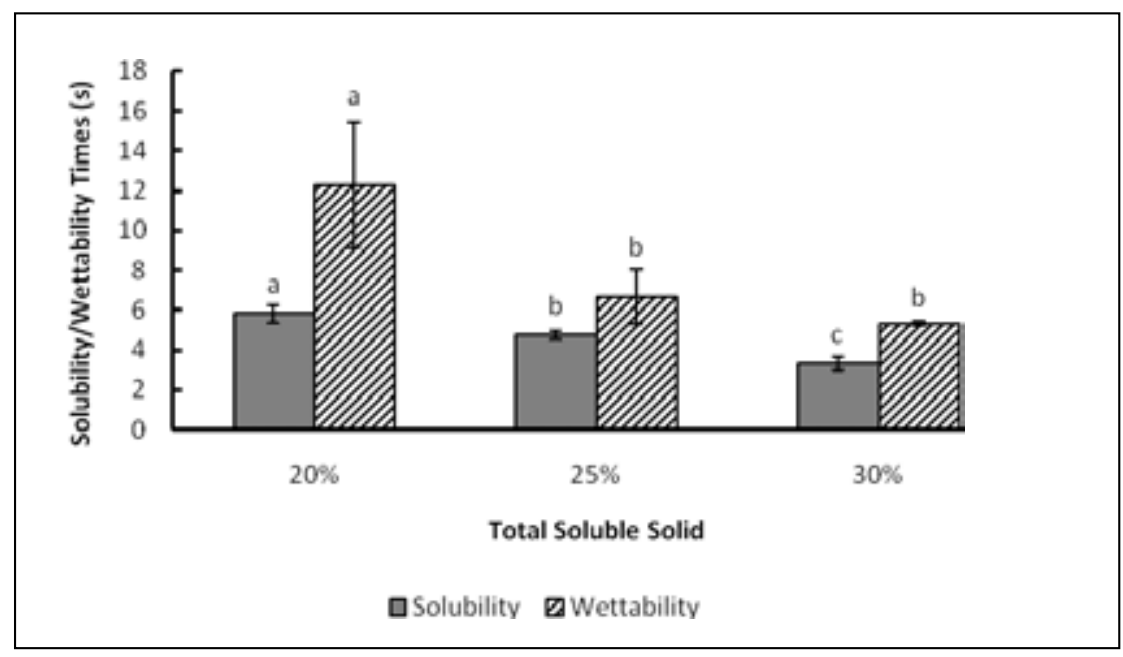

Figure 1. Solubility and wettability times of Aloe vera powder 
Maltodextrin addition causes a decrease in solubility and wettability time because maltodextrin is a group of starch that has hydrophilic properties that can increase wetting ability, so the solubility time becomes short. The more maltodextrin addition, the more hydrophilic components are, which increased powder ability to dissolve in water. According to Lane and Medeiros in Marques et al. (2014), the proper parameter for wetting time is 5 minutes. This study showed that Aloe vera powder with the highest maltodextrin addition has wettability time of 5.53 minutes.
The process should be improved to produce Aloe vera powder with shorter wetting time.

\section{Aloe vera Powder Microscopic Structure}

Particle size control in drying process is an important factor because it will affect the appearance, flowability, and dispersibility (Marques et al., 2014). Aloe vera powder was assessed using Scanning Electron Microscopy to know the detail about particle size (Figure 2).
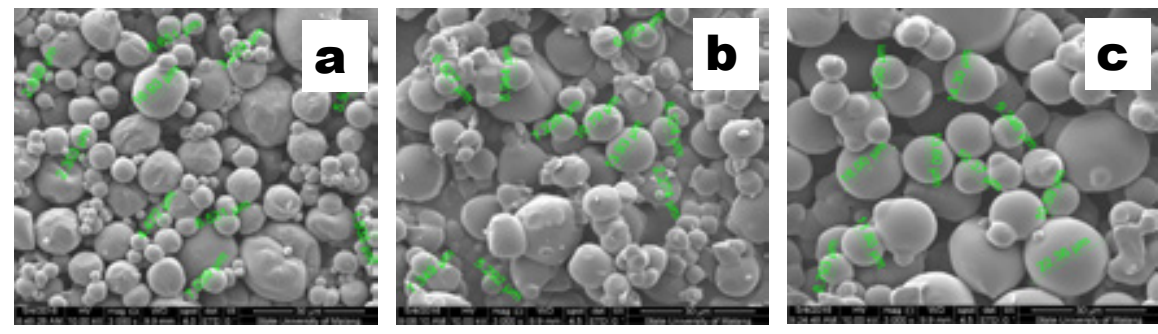

Figure 2. Microscopic images of Aloe vera powder with total soluble solid content of (a) $20 \%$; (b) $25 \%$; (c) $30 \%$ (w/v)

Aloe powder with various maltodextrin additions in electron photomicrographs scan showed that the granules have uniform rounded shape. Aloe vera powder granules size varies between 1-18 $\mu \mathrm{m}$. Maltodextrin addition of $20 \%, 25 \%$, and $30 \%(\mathrm{w} / \mathrm{v})$ yielded powder with average granular size in $5.73 \pm 4.41 ; 7.76 \pm 3.12 ; 12.85 \pm 4.39 \mu \mathrm{m}$, respectively. Higher maltodextrins addition increased the mean particle size of Aloe vera powder.

\section{CONCLUSION}

Maltodextrin from cassava was found to be suitable carrier to produce Aloe vera powder by spray drying. The addition of maltodextrin that gives total soluble solid $30 \%(\mathrm{w} / \mathrm{v})$ on Aloe vera extract before drying process produces Aloe vera powder with the lowest water content and the biggest particle size. Maltodextrin addition caused brighter Aloe vera powder and improves its flowability. This process require to be improved to produce Aloe vera powder with shorter wetting time.

\section{ACKNOWLEDGMENT}

This research was financially supported by Directorate General of Higher Education, Ministry of Research, Technology, and Higher Education of the Republic of Indonesia.

\section{REFERENCES}

1. Caliskan, G and Dirim, S.N. 2016. The effect of different processes and the amounts of maltodextrin addition on the powder properties of sumac extract powder. Powder Technology; 287: 308-314.

2. Eshun, $\mathrm{K}$ and $\mathrm{He}, \mathrm{Q} .2004$. Aloe vera: a valuable ingredient for the food, pharmaceutical, and cosmetic industries - a review. Critical Reviews in Food Science and Nutrition; 44(2): 91-96.

3. Gong, Z., Zhang, M., Mujumdar, A.S., Sun, J. 2008. Spray drying and 
agglomeration of instant bayberry powder. Drying Technology; 26: 116121.

4. Jinapong, N., Suphantarika, M., Jamnong, P. 2008. Production of instant soymilk powders by ultrafiltration, spray drying, and fluidized bed agglomeration. Journal of Food Engineering; 84: 194-205: (2008).

5. Johnson, R., G. Padmaja, and S.N. Moorthy. 2009. Comparative production of glucose and high fructose syrup from cassava and sweet potato roots by direct conversion technique. Innovative Food Science and Emerging Technologies 10 (2009):616-620

6. Lee, J.K., Lee, M.K., Yun, Y.P., Kim, Y., Kim, J.S., Kim, Y.S., 2001. Acemannan purified from Aloe vera induces phenotypic and functional maturation of immature dendritic cells. International Immunopharmacology; 1(7): 1275-1284.

7. Lopez-malo, A., Palou, E., BarbosaCanovas, G.V., Welti-Chanes, J., Swanson, B.G. 1998. Polyphenoloxidase activity and color changes during the storage of high hydrostatic pressure treated avocado puree. Food Research International; 31(8): 549-556: (1998).

8. Marques, G.R., Borges, S.V., deMendonca, K.S., Fernandes, R.V.B., Meneves, E.G.T. 2014. Application of maltodextrin in green corn extract powder production. Powder Technology; 263: 89-95.

9. Matsuura, T., Ogawa, A., Tomabechi, M., Matsuhita, R., Gohtani, S., Neoh, T.L., Yoshii, H. 2015. Effect of dextrose equivalent of maltodextrin on the stability of emulsified coconutoil in spray-dried powder. Journal of Food Engeneering; 163: 54-59.

10. Ozdikicierler, O., Dirim, S.N., Pazir, F. 2014. The effect of spray drying process parameters on the characteristic process indices and rheological powder properties of microencapsulated plant (Gypsophila) extract powder. Powder Technology; 253: 474-480.

11. Quek, S.Y., Chok, N.K., Swedlund, P. 2007. The physicochemical properties of spray-dried water-melon powders. Chemical Engi-neering Processing; 46: 386-392.

12. Rahayuni, T. 2002. Mikroenkap-sulasi ekstrak lidah buaya (Aloe vera): Uji karakteristik enkapsulan dan aktivitas antioksidannya. Thesis. Prodi Teknologi Hasil Perkebunan. Fakultas Teknologi Pertanian. Universitas Gadjah Mada Yogyakarta.

13. Reynolds, T. and Dweck, A.C. 1999. Aloe vera leaf gel: a review update. Journal of Ethnopharmacology; 68(13): 3-37.

14. Shanavas, S., G. Padmaja, S.N. Moorthy, M.S. Sajeev, and J.T. Sheriff. 2011. Process optimization for bioethanol pro-duction from cassava starch using novel eco-friendly enzymes. Biomass and Bioenergy, 35 (2011): 901-909

15. Udomrati, S. and Gohtani, S. 2015. Tapioca maltodextrin fatty acid ester as a potential stabilizer for Tween 80-stabilized oil-in-water emulsions. Food Hidrocolloyd; 44: 23-31.

16. Vogler, B.K. and Ernest, E. 1999. Aloe vera: a systemic review of its clinical effectiveness. British journal of General Practice; 49 (447): 823-828.

17. Wang, Z.I., Finlay, W.H., Peppler, M.S., Sweeney, L.G. 2006. Pow-der Formation by atmospheric sprayfreeze-drying. Powder Technology; 170: 45-52.

18. Yagi, A., Tsunoda, M., Egusa, T., Akasaki, K., Tsuji, H. 1998. Immunochemical distinction of Aloe vera, $A$. arborescens, and $A$. chinensis gels. Planta Medica; 64(3): 277-278. 